\title{
Pengaruh Kompetensi dan Komitmen Organisasional Terhadap Kinerja Guru dan Pegawai pada SMP dan SMA Muhammadiyah 2 Singaraja
}

\author{
Sarif Hidayat ${ }^{* 1}$, Komang Krisna Heryanda ${ }^{2}$ \\ 1,2Program Studi Manajemen \\ Universitas Pendidikan Ganesha \\ Singaraja, Indonesia \\ e-mail: syahidbali95@gmail.com ${ }^{* 1}$, krisna.heryanda@undiksha.ac.id²
}

Pengutipan:

Hidayat, S. \&

Heryanda, K.K

(2021). Pengaruh

Kompetensi dan

Komitmen

Organisasional

Terhadap Kinerja

Guru dan

Pegawai pada

SMP dan SMA

Muhammadiyah 2

Singaraja. Jurnal

Pendidikan

Ekonomi

Undiksha, 13(1),

146-151

http://dx.doi.org/1

$\underline{0.23887 / \text { ijpe.v13i }}$

1.32651

\begin{abstract}
Abstrak
Riwayat Artikel Tanggal diajukan: 25 Februari 2021

Tanggal diterima : 17 Mei 2021

Tanggal

dipublikasikan:

25 Juni 2021.

Penelitian ini bertujuan untuk menguji pengaruh kompetensi dan komitmen organisasional terhadap kinerja guru dan pegawai pada SMP dan SMA Muhammadiyah 2 Singaraja secara parsial dan secara simultan. Rancangan penelitian yang digunakan dalam penelitian ini adalah kuantitatif kausal. Subjek dalam penelitian ini adalah guru dan pegawai pada SMP dan SMA Muhammadiyah 2 Singaraja sedangkan objek penelitian ini adalah kompetensi, komitmen organisasional dan kinerja karyawan. Populasi penelitian yang digunakan berjumlah 37 orang karyawan. Data dikumpulkan dengan kuesioner dan wawancara kemudian dianalisis menggunakan analisis regresi linear berganda. Hasil penelitian ini menunjukkan (1) kompetensi dan komitmen organisasional berpengaruh signifikan terhadap kinerja karyawan, (2) kompetensi berpengaruh positif terhadap kinerja karyawan, dan (3) komitmen organisasional berpengaruh positif terhadap kinerja karyawan.
\end{abstract}

Kata kunci: kinerja karyawan; komitmen organisasional; kompetensi.

\begin{abstract}
This research aims to examine the effect of competence and organizational commitment on the performance of teachers and employees at SMP and SMA Muhammadiyah 2 Singaraja, namely partially and simultaneously. The research design used in this research is quantitative causal. The subjects in this study were teachers and employees at SMP and SMA Muhammadiyah 2 Singaraja while the objects of this study were competence, organizational commitment and employee performance. The research population used was 37 employees. The data collected by results of questionnaires and interviews were then analyzed by multiple regression analysis. The results of this study indicate (1) competence and organizational commitment have a significant effect on employee performance, (2) competence has a positive effect on employee performance, and (3) organizational commitment has a positive effect on employee performance.
\end{abstract}

Keywords : employee performance; organizational commitment; competence.

\section{PENDAHULUAN}

Sumber daya manusia merupakan aset utama suatu organisasi yang menjadi perencana dan pelaku aktif dari setiap aktivitas organisasi. Mereka mempunyai pikiran, perasaan, keinginan, status, latar belakang pendidikan, dan motivasi yang heterogen yang dibawa kedalam suatu 
organisasi sehingga tidak seperti mesin, uang dan material yang sifatnya statis dan dapat dikuasai serta diatur sepenuhnya dalam mendukung tercapainya tujuan. Sumber daya manusia yang cakap, tidak selalu menjamin produktivitas kerja yang baik, apabila nilai suatu kepuasan dalam pekerjaannya masih tergolong rendah. Kualitas sumber daya manusia dalam suatu organisasi hendaknya disesuaikan dengan kebutuhan organisasi yang bersangkutan agar efektif dan efisien dalam mencapai tujuan.

Sebagai aset utama, maka sumber daya manusia (SDM) dalam perusahaan harus ditingkatkan produktivitasnya dengan menciptakan kondisi dan lingkungan kerja yang dapat mendorong karyawan untuk meningkatkan kompetensi, kemampuan dan keterampilan yang dimiliki secara optimal, meningkatkan komitmen terhadap perusahaan serta bisa mengembangkan karirnya agar lebih maju. Wujud dari hasil pemeliharaan dan pengembangan sumber daya ini adalah tumbuhnya rasa betah dan adanya kemauan untuk bekerja dengan sebaikbaiknya pada perusahaan atau organisasi tempat mereka bekerja. Akan tetapi, realitas yang ada sehari-hari justru sebaliknya. Sering dijumpai karyawan yang sekadar hanya melaksanakan tugasnya tanpa disertai kreasi, improvisasi dan inovasi bekerja yang memadai.

Sekolah Menengah Pertama dan Sekolah Menengah Atas Muhammadiyah 2 Singaraja adalah salah satu amal usaha yang di miliki oleh Muhammadiyah yang berada di bawah naungan Majelis Dikdasmen Pimpinan Daerah Muhammadiyah Kabupaten Buleleng. Berdasarkan observasi yang dilakukan di lokasi penelitian yaitu pada Sekolah Menengah Pertama dan Sekolah Menengah Atas Muhammadiyah 2 Singaraja secara umum kompetensi guru dan karyawan masih ada beberapa guru yang mengajar tidak sesuai dengan bidang ilmu yang dimilikinya. Kompetensi yang dimiliki guru di Sekolah Menengah Pertama dan Sekolah Menengah Atas Muhammadiyah 2 Singaraja masih perlu ditingkatkan, guru perlu menerapkan berbagai strategi pembelajaran, menganalisis kelemahan dan kekuatan pembelajaran, memahami materi ajar yang ada dalam kurikulum dan memahami konsep antar mata pelajaran terkait. Fenomena lain yang berkaitan dengan kompetensi adalah masih ada ketidak sesuaian bidang ilmu yang dimiliki guru dengan mata pelajaran yang diajarkan. Kurangnya pengetahuan guru tentang mata pelajaran yang diajarkan dapat mempengaruhi proses belajar mengajar siswa. Guru Merupakan salah satu faktor yang dapat mempengaruhi berhasil tidaknya proses belajar siswa. Hal ini tentu kurang sesuai dengan tugas guru adalah mengajar sesuai bidang keahliannya.

Selain kompetensi, baik atau buruknya keberhasilan atau pencapaian pada tujuan organisasi dibutuhkan komitmen yang kuat dari setiap guru dan karyawan. Komitmen guru dan karyawan dapat dilihat dari keseriusan untuk bersama dan bertahan bekerja pada organisasi. Keberhasilan manajemen suatu organisasi, salah satunya ditentukan oleh keberhasilan manajemen dalam menumbuhkan komitmen organisasional pegawai. Seberapa jauh komitmen organisasional pegawai terhadap organisasi akan sangat menentukan pencapaian tujuan organisasi. Komitmen organisasional karyawan sangatlah penting, karena pegawai yang memiliki komitmen yang kuat terhadap organisasi akan menampilkan kinerja terbaiknya serta produktif mengemban pekerjaan.

Kinerja guru dan pegawai pada SMP dan SMA Muhammadiyah 2 Singaraja juga menunjukkan bahwa terjadi penurunan kinerja dari tahun 2018 dan 2019. Berdasarkan uraian tersebut, maka penulis tertarik untuk melakukan penelitian dengan judul Pengaruh Kompetensi dan Komitmen Organisasional terhadap Kinerja Guru dan Pegawai pada Sekolah Menengah Pertama dan Sekolah Menengah Atas Muhammadiyah 2.

Kajian Pustaka Dan Perumusan Hipotesis Hubungan Kompetensi Dan Komitmen Organisasional Terhadap Kinerja Pegawai. Kompetensi dan Komitmen organisasional secara bersama-sama dapat mempengaruhi kinerja karyawan. 
Karyawan dengan kompetensi yang memadai dan memiliki komitmen terhadap organisasi dapat menghasilkan kinerja yang maksimal. Hal ini didukung dengan hasil penelitian (Laelani, 2016) yang menemukan bahwa kompetensi dan komitmen organisasional karyawan mempunyai pengaruh signifikan terhadap kinerja karyawan

$\mathrm{H} 1$ : Ada pengaruh kompetensi dan komitmen organisasional terhadap kinerja pegawai pada SMP dan SMA Muhammadiyah 2 Singaraja.

\section{Hubungan Kompetensi Terhadap Kinerja Pegawai}

Menurut Spencer (Sudarmanto, 2009), karakteristik dasar kompetensi memiliki hubungan kausal atau sebab akibat dengan kriteria yang dijadikan acuan efektif atau berperformansi superior ditempat kerja atau situasi tertentu. Kompetensi yang mencakup motif, watak, konsep diri, pengetahuan dan keterampilan akan menentukan bagaimana perilaku orang dalam bekerja. Perilaku yang merupakan tindakan seseorang dalam pekerjaan juga ditentukan oleh sejauh mana ia didukung oleh keterampilan atau keahlian yang dimiliki. Asumsinya, semakin terampil seseorang atau semakin ahli seseorang dalam pekerjaan tertentu, maka akan semakin mendorong penampilan kerja yang baik atau unggul (Sudarmanto, 2009)

Pendapat tersebut di atas didukung oleh (Fitriana, 2014) yang menyatakan ada pengaruh positif dari kompetensi terhadap kinerja karyawan.

$\mathrm{H} 2$ : Ada pengaruh kompetensi terhadap kinerja pegawai pada SMP dan SMA Muhammadiyah 2 Singaraja.

\section{Hubungan Komitmen Organisasional Terhadap Kinerja Karyawan}

(Wright, Charles, 1992) menyatakan bahwa semakin tinggi komitmen seseorang terhadap tugasnya maka akan semakin tinggi kinerja yang akan dihasilkan, yang menuju pada tingkat penilaian yang semakin tinggi. Hal serupa juga dikemukakan oleh (V. Rivai, 2005) yang menyatakan bahwa komitmen organisasional berpengaruh signifikan terhadap kinerja. Semakin tinggi komitmen organisasional dari karyawan maka akan semakin meningkat kinerja individual karyawan (Aprilia \& Hudiwinarsih., 2012).

H3: Ada pengaruh komitmen organisasional terhadap kinerja pegawai pada SMP dan SMA Muhammadiyah 2 Singaraja .

\section{METODE}

Penelitian ini dilakukan pada SMP dan SMA Muhammadiyah 2 Singaraja. Rancangan penelitian yang digunakan dalam penelitian ini adalah kuantitatif kausal. Dalam penelitian ini kompetensi dan komitmen organisasional dijadikan sebagai variabel bebas serta kinerja karyawan sebagai variabel terikat. Subjek dalam penelitian ini adalah guru dan pegawai pada SMP dan SMA Muhammadiyah 2 Singaraja dan objeknya yaitu kompetensi, komitmen organisasional serta kinerja pegawai pada SMP dan SMA Muhammadiyah 2 Singaraja. Populasi dalam penelitian ini adalah guru dan pegawai pada SMP dan SMA Muhammadiyah 2 Singaraja yang berjumlah 37 orang.

Dalam penelitian ini terdapat dua jenis data menurut sifatnya yaitu: (1) kualitatif adalah data yang tidak berbentuk angka. Data yang didapat berupa latar belakang sejarah organisasi, struktur organisasi dan data lain yang diambil dari data organisasi, (2) kuantitatif adalah data yang berbentuk angka. Data yang dipakai dalam penelitian ini yaitu standar kinerja dan pencapaian kerja serta jumlah pegawai. Sedangkan ditinjau dari sumbernya, data yang digunakan dalam penelitian ini yaitu (1) data primer yang berupa kompetensi pegawai, komitmen organisasional dan kinerja pegawai, (2) data sekunder yang berupa hasil telaah data kuantitatif.

Teknik pengumpulan data yang digunakan dalam memperoleh data penelitian adalah, (1) teknik Kuesioner. Data yang diperoleh yaitu data tanggapan karyawan terhadap kompetensi, komitmen organisasional, dan kinerja karyawan. (2) Wawancara. Berfungsi sebagai metode pelengkap untuk mendapat informasi 
secara lisan dengan tujuan agar mendapatkan data untuk menjelaskan permasalahan, wawancara dilakukan langsung dengan pimpinan dan beberapa pegawai pada SMP dan SMA Muhammadiyah 2 Singaraja.

Instrumen penelitian yang digunakan dalam penelitian ini adalah kuesioner yang berisi daftar pertanyaan yang disebar kepada responden dan wawancara sebagai instrumen pengumpulan data dalam bentuk pedoman wawancara. Terdapat dua uji yang dilakukan dalam instrumen penelitian yaitu: (1) pengujian validitas instrumen, (2) pengujian reliabilitas instrumen.

Analisis data dalam penelitian ini menggunakan analisis regresi berganda, yaitu analisis yang digunakan untuk menganalisis besarnya hubungan dan pengaruh kompetensi (X1) dan komitmen organisasional (X2) terhadap kinerja guru dan pegawai $(Y)$.

\section{HASIL DAN PEMBAHASAN}

Hasil penelitian dilakukan dengan menggunakan metode analisis regresi berganda untuk mengetahui pengaruh pada kompetensi dan komitmen organisasional terhadap kinerja guru dan pegawai pada SMP dan SMA Muhammadiyah 2 Singaraja, populasi penelitian menggunakan 37 pegawai. Perhitungan uji statistik analisis regresi berganda menggunakan bantuan Program SPSS 16.0 For Windows. Berdasarkan hasil analisis regresi berganda Pengaruh Kompetensi (X1) dan Komitmen Organisasional (X2) Terhadap Kinerja Pegawai (Y) dapat disimpulkan hubungan antar variabel sebagai berikut. Pertama, ada pengaruh dari kompetensi dan komitmen organisasional terhadap kinerja karyawan pada SMP dan SMA Muhammadiyah 2 Singaraja, hal tersebut ditunjukkan dengan nilai $p$-value Ryx1x2 = $0,000<$ alpha $(\alpha)=0,05$. Besar pengaruh kompetensi dan komitmen organisasional terhadap kinerja pegawai adalah 0,680. Hasil tersebut menunjukkan bahwa sebesar 68,0\% kinerja pegawai dipengaruhi oleh variabel kompetensi dan komitmen organisasional dengan besar sumbangan pengaruh kompetensi dan komitmen organisasional terhadap kinerja pegawai sebesar $46,3 \%$, sedangkan $32,0 \%$ kinerja pegawai dipengaruh oleh variabel lain diluar variabel kompetensi dan komitmen organisasional. Kedua, ada pengaruh dari kompetensi terhadap kinerja pegawai pada SMP dan SMA Muhammadiyah 2 Singaraja, hal tersebut ditunjukkan dengan nilai $p$-value $\mathrm{Ryx} 1=$ $0,000<$ alpha $(\alpha)=0,05$. Besar pengaruh kompetensi terhadap kinerja pegawai adalah 0,607. Hasil tersebut menunjukkan bahwa sebesar $60,7 \%$ kinerja dipengaruhi oleh variabel kompetensi dengan besar sumbangan pengaruh kompetensi terhadap kinerja pegawai sebesar $36,8 \%$. Ketiga, ada pengaruh dari komitmen organisasional terhadap kinerja pegawai pada SMP dan SMA Muhammadiyah 2 Singaraja, hal tersebut ditunjukkan dengan nilai $p$-value Ryx2 $=0,000<$ alpha $(\alpha)=$ 0,05. Besar pengaruh komitmen organisasional terhadap kinerja pegawai adalah 0,352. Hasil tersebut menunjukkan bahwa sebesar $35,2 \%$ kinerja karyawan dipengaruhi oleh variabel komitmen organisasional dengan besar sumbangan pengaruh komitmen organisasional terhadap kinerja pegawai sebesar $12,3 \%$.

\section{Pembahasan}

Berdasarkan hasil penelitian variabel kompetensi dan komitmen organisasional menunjukkan bahwa kinerja pegawai pada SMP dan SMA Muhammadiyah 2 Singaraja dapat dipengaruhi oleh keduanya secara bersamaan. Hasil penelitian ini diperkuat oleh penelitian sebelumnya yang dilakukan oleh (Ahdian, 2017) yang dengan hasil analisis terdapat pengaruh yang signifikan antara variabel kompetensi dan komitmen organisasional terhadap kinerja karyawan.

$$
\text { Hasil penelitian selanjutnya }
$$

menjelaskan bahwa kompetensi berpengaruh terhadap kinerja pegawai pada SMP dan SMA Muhammadiyah 2 Singaraja. Hal ini didukung oleh teori McClelland dalam (Rivai, 2013) yang mendefinisikan kompetensi (Competency) sebagai karakteristik yang mendasar yang dimiliki seseorang yang berpengaruh langsung terhadap atau dapat memprediksi kinerja yang sangat baik. Adapun teori lainnya yang mendukung adalah kajian 
empiris dari (Anggraeni, 2015) yang menyatakan ada pengaruh positif dari kompetensi terhadap kinerja karyawan. Hasil penelitian ini sesuai dengan dua teori para ahli tersebut, dan dapat disimpulkan dari pernyataan tersebut bahwa kompetensi berpengaruh terhadap kinerja karyawan.

Penelitian selanjutnya menunjukkan hasil bahwa komitmen organisasional berpengaruh terhadap kinerja pegawai pada SMP dan SMA Muhammadiyah 2 Singaraja. Hasil ini didukung oleh teori (Meyer, 1997) yang mendefinisikan komitmen organisasional merupakan keyakinan yang menjadi pengikat pegawai dengan organisasi tempatnya bekerja, yang ditunjukkan dengan adanya loyalitas, keterlibatan dalam pekerjaan, dan identifikasi terhadap nilai-nilai dan tujuan organisasi. Hal serupa juga dikemukakan oleh ( Rivai, 2005) yang menyatakan bahwa komitmen organisasional berpengaruh signifikan terhadap kinerja. Semakin tinggi komitmen organisasional dari karyawan maka akan semakin meningkat kinerja individual karyawan (Aprilia \& Hudiwinarsih., 2012)

\section{SIMPULAN DAN SARAN}

Simpulan

Berdasarkan populasi penelitian dari 37 orang pegawai pada SMP dan SMA Muhammadiyah 2 Singaraja dapat ditarik simpulan sebagai berikut. Pertama, kompetensi dan komitmen organisasional berpengaruh signifikan terhadap kinerja pegawai. Kedua, kompetensi berpengaruh positif terhadap kinerja pegawai. Ketiga, komitmen organisasional berpengaruh positif terhadap kinerja pegawai.

Saran

Berdasarkan simpulan di atas, saran yang diajukan adalah sebagai berikut. Pertama, diharapkan bisa meningkatkan kinerja karyawan dengan menempatkan pegawai sesuai dengan keahlian yang dimiliki dan memperhatikan kenyamanan kerja dari masing-masing pegawai. Kedua, Bagi peneliti selanjutnya yang tertarik untuk melanjutkan penelitian mengenai kompetensi, komitmen organisasional serta kinerja karyawan diharapkan untuk mengembangkan penelitian ini dengan menggunakan populasi dan sampel yang lebih luas, sehingga hasil penelitian yang didapat lebih lengkap, dan menggunakan variabel lain yang dapat mempengaruhi kinerja karyawan.

\section{DAFTAR PUSTAKA}

Ahdian, M. (2017). Pengaruh Kompetensi, Komitmen Organisasi Dan Pengembangan Karir Terhadap Kinerja Karyawan PT. Tanjungkreasi Parquet Industri Temanggung. Surakarta: IAIN.

Anggraeni, B. (2015). Pengaruh Pengetahuan Kewirausahaan dan Lingkungan Keluarga Terhadap Minat Berwirausaha Siswa Kelas XI SMK Islam Nusantara Comal Kabupaten Pemalang. Jurnal Pendidikan Ekonomi Dinamika Pendidikan, 10(1), 42-52.

Aprilia, M., \& Hudiwinarsih., G. (2012). Pengaruh Kompensasi, Motivasi Dan Komitmen Organisasional Terhadap Kinerja Karyawan Bagian Akuntansi (Studi Empiris Pada Perusahaan Manufaktur Di Surabaya). Jurnal Indonesia Accounting, 2(2), 215-228.

Fitriana, R. N. (2014). Hubungan Self Efficacy Dengan Tingkat Pengetahuan Ibu Dalam Penanganan Pertama Luka Bakar Pada Anak Usia Pra-Sekolah Di Desa Jombor Bendosari Sukoharjo. Artikel.Stikes KusumaHusada Surakarta.

Laelani, S. (2016). Pengaruh Kompetensi dan Komitmen Organisasional Karyawan Terhadap Kinerja Karyawan (Studi Kasus pada PT Utomo Ladju). Jakarta: UIN Syarif Hidayatullah.

Meyer, A. \&. (1997). Commitment In The Workplace (Theory, Research and Application). Sage Publication London.

Rivai, dan B. (2005). Manajemen Sumber Daya Manusia Untuk Perusahaan,. Jakarta: Rajagrafindo Persada.

Rivai, V. (2005). Manajemen Sumber Daya Manusia Untuk Perusahaan Dari teori Ke Praktik. Jakarta: PT. Raja Grafindo Persada.

Rivai, V. (2013). Manajemen Sumber Daya 
p-ISSN : 2599-1418

Jurnal Pendidikan Ekonomi Undiksha

e-ISSN : 2599-1426

Vol. 13 No. 1 (2021)

Manusia Untuk Perusahaan, Cetakan

Pertama,. Jakarta, PT. Raja

GrafindoPersada.

Sudarmanto. (2009). Kinerja dan Pengembangan Kompetensi SDM.

Yogyakarta: Pustaka Pelajar.

Wright, Charles, R. (1992). Sosiologi Komunikasi Massa. Bandung: Remaja Karya. 